Review

\title{
Durability of alkali-activated binders: A clear advantage over Portland cement or an unproven issue?
}

\author{
F. Pacheco-Torgal ${ }^{\text {a,* }}$, Z. Abdollahnejad ${ }^{\mathrm{a}}$, A.F. Camões ${ }^{\mathrm{b}}$, M. Jamshidi ${ }^{\mathrm{c}}$, Y. Ding ${ }^{\mathrm{d}}$ \\ a University of Minho, C-TAC Research Unit, Guimarães, Portugal \\ ${ }^{\mathrm{b}}$ University of Minho, Department of Civil Engineering, Guimarães, Portugal \\ ${ }^{\mathrm{c}}$ Department of Polymer, Building and Housing Research Center (BHRC), Amirkabir University of Technology, Tehran Polytechnic, Iran \\ ${ }^{\mathrm{d}}$ State Key Laboratory of Coastal and Offshore Engineering, Dalian University of Technology, Dalian, China
}

\section{A R T I C L E I N F O}

\section{Article history:}

Received 6 September 2011

Received in revised form 28 November 2011

Accepted 4 December 2011

\section{Keywords:}

Alkali-activated binders

Ordinary Portland cement

Eco-efficiency

Durability

Efflorescences

\begin{abstract}
A B S T R A C T
The alkali activation of alumino-silicate materials is a complex chemical process evolving dissolution of raw materials, transportation or orientation and polycondensation of the reaction products. Publications on the field of alkali-activated binders, state that this new material is likely to have high potential to become an alternative to Portland cement. While some authors state that the durability of these materials constitutes the most important advantage over Portland cement others argue that it's an unproven issue. This paper presents a review of the literature about the durability of alkali-activated binders. The subjects of this paper are resistance to acid attack, alkali-silica reaction, corrosion of steel reinforcement, resistance to high temperatures and to fire, resistance to freeze-thaw. Special attention is given to the case of efflorescences, an aspect that was received very little concern although it is a very important one.
\end{abstract}

(c) 2011 Elsevier Ltd. All rights reserved.

\section{Contents}

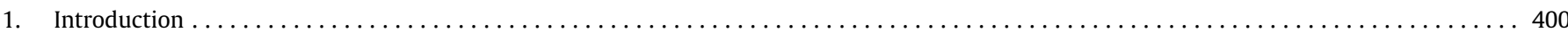

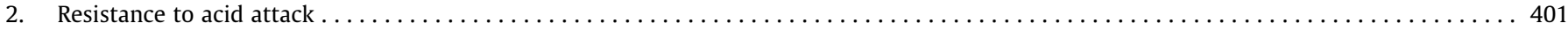

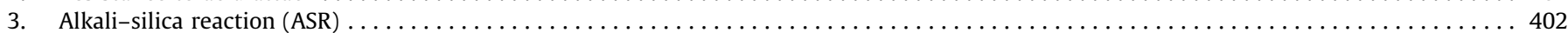

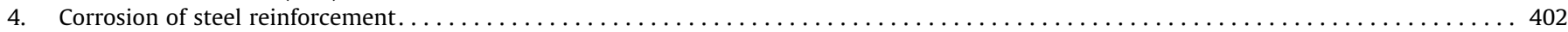

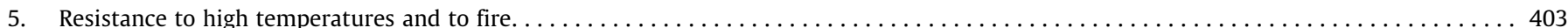

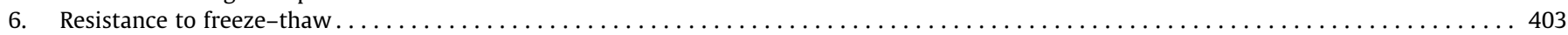

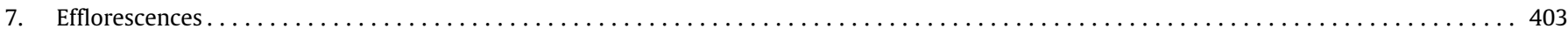

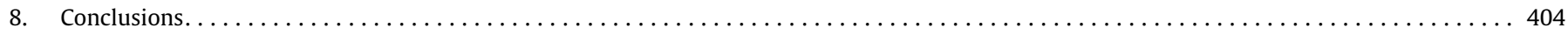

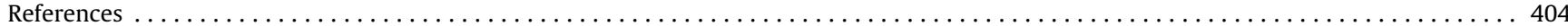

\section{Introduction}

With an annual production of almost 3 Gt Ordinary Portland cement (OPC) is the dominant binder of the construction industry [1]. The production of one tonne of OPC generates 0.55 tonnes of chemical $\mathrm{CO}_{2}$ and requires an additional 0.39 tonnes of $\mathrm{CO}_{2}$ in fuel emissions for baking and grinding, accounting for a total of 0.94 tonnes of $\mathrm{CO}_{2}$ [2]. Other authors [3] reported that the cement industry emitted in 2000 , on average, $0.87 \mathrm{~kg}$ of $\mathrm{CO}_{2}$ for every $\mathrm{kg}$ of cement

\footnotetext{
* Corresponding author. Tel.: +351 253 510200; fax: +351253510213.

E-mail address: torgal@civil.uminho.pt (F. Pacheco-Torgal).
}

produced. As a result the cement industry contributes about $7 \%$ of the total worldwide $\mathrm{CO}_{2}$ emissions [4]. The projections for the global demand of Portland cement show that in the next 40 years it will have a twofold increase reaching $6 \mathrm{Gt} / \mathrm{year}$ [5]. The urge to reduce carbon dioxide emissions and the fact that OPC structures which have been build a few decades ago are still facing disintegration problems points out the handicaps of OPC. Portland cement based concrete presents a higher permeability that allows water and other aggressive media to enter leading to carbonation and corrosion problems. The early deterioration of reinforced concrete structures based on Ordinary Portland cement (OPC) is a current phenomenon with significant consequences both in terms of the cost for the rehabilitation of these structures, or even in terms of environmental 
impacts associated with these operations. Research works [6-8] carried out so far in the development of alkali-activated cements showed that much has already been investigated and also that an environmental friendly alternative to Portland cement is rising. Davidovits et al. [9] was the first author to address the carbon dioxide emissions of these binders stating that they generate just 0.184 tons of $\mathrm{CO}_{2}$ per ton of binder. Duxson et al. [10] do not confirm these numbers; they stated that although the $\mathrm{CO}_{2}$ emissions generated during the production of $\mathrm{Na}_{2} \mathrm{O}$ are very high, still the production of alkali-activated binders is associated to a level of carbon dioxide emissions lower than the emissions generated in the production of OPC. According to those authors the reductions can go from $50 \%$ to 100\%. Duxson and Van Deventer [11] mention an independent study made by Zeobond Pty. Ltd. in which a low emissions Portland cement ( 0.67 ton/ton) and alkali-activated binders were compared, reporting that the latter had $80 \%$ lower $\mathrm{CO}_{2}$ emissions. Weil et al. [12] mentioned that the sodium hydroxide and the sodium silicate are responsible for the majority of $\mathrm{CO}_{2}$ emissions in alkali-activated binders. These authors compared Portland cement concrete and alkali-activated concrete with similar durability reporting that latter have $70 \%$ lower $\mathrm{CO}_{2}$ emissions which confirmed the aforementioned reductions. McLellan et al. [13] reported a $44 \%$ to $64 \%$ reduction in greenhouse gas emissions of alkali-activated binders when compared to OPC. Habert et al. [14] carry out a detailed environmental evaluation of alkali activated binders using the Life Cycle Assessment methodology confirming that they have a lower impact on global warming than OPC but on the other side they have a higher environmental impact regarding other impact categories. The high cost of alkali-activated binders is one of the major factors which still remain a severe disadvantage over Portland cement [14]. Therefore, investigations about the replacement of waterglass by sodic wastes are needed [15]. Currently alkali-activated binders only becomes economic competitive for high performance structural purposes, because the cost of alkali-activated concretes is located midway between OPC concretes and high performance concretes. Since the average ERMCO concrete class production lies between C25/30 and $\mathrm{C} 30 / 37$ and only $11 \%$ of the concrete ready-mixed production is above the strength class C35/45 [16], this means that alkali-activated binders are targeting a small market share. Therefore, in the short term the above cited disadvantage means that the study of alkali-activated applications should focus on high cost materials such as, commercial concrete repair mortars. Pacheco-Torgal [17-20] showed that alkali-activated mortars can be as much as 7 times cheaper than current commercial repair mortars thus pointing a viable alternative for alkali-activated binders. These materials are still at the beginning stages of development and hence need further research work in order to become technically and economically viable construction materials. Besides the durability of alkali-activated binder is a subject of some controversy, while Duxson et al. [10] state this is the most important issue on determining the success of these new materials and other authors [21] mention that the fact that samples from the former Soviet Union that have been exposed to service conditions for in excess of 30 years showing little degradation means that geopolymers do therefore appear to stand the test of time. But since those materials were of the ( $\mathrm{Si}+\mathrm{Ca}$ ) type that conclusion cannot be extended to geopolymers defined as "alkali aluminosilicate gel, with aluminium and silicon linked in a tetrahedral gel framework" [11]. On the other side Juenger et al. [1] argue that "The key unsolved question in the development and application of alkali activation technology is the issue of durability" and more recently Van Deventer et al. [22] recognized that "whether geopolymer concretes are durable remains the major obstacle to recognition in standards for structural concrete". In this work relevant knowledge about the durability alkali-activated cements will be reviewed. The subjects of this paper are as follows:

\section{Resistance to acid attack}

Several authors reported that chemical resistance is one of the major advantages of alkali-activated binders over Portland cement. Glukhovsky [23], used alkali-activated slag mortars noticing that they showed increase tensile strength even after being immersed in lactic and hydrochloric acid solutions $(\mathrm{pH}=3)$. Other authors [24] studied the exposure of alkali-activated slag mortars during six months in $5 \%$ acid solution concentration, reporting that for citric acid changes were low, for nitric and hydrochloric acid changes were moderate although severe changes was noticed when sulphuric acid was used. Davidovits et al. [9] reported mass losses of $6 \%$ and $7 \%$ for alkali-activated binders immersed in $5 \%$ concentration hydrochloric and sulphuric acids during 4 weeks. For the same conditions he also reported that Portland cement based concretes suffered mass losses between 78\% and 95\%. Palomo et al. [25] studied metakaolin mixtures activated with $\mathrm{NaOH}$ and waterglass when submitted to, sulphuric acid $(\mathrm{pH}=3)$, sea water $(\mathrm{pH}=7)$ and sodium sulphate $(\mathrm{pH}=6)$, during 90 days. They reported a minor flexural strength decrease from 7 to 28 days immersion, between 28 and 56 days flexural strength rises, decreasing again from 56 to 90 days and rising from that day forward. They reported that behaviour was similar to the several acid solutions. According to these authors, unreacted sodium particles are not in the structure of the hardened material, remaining in a soluble condition thus when in contact with a solution they are leached increasing the binder porosity and lowering mechanical strength. On the other hand, strength increase after 3 months indicates that the reaction process is still evolving, with the formation of zeolitic precipitates (faujasite) thus lowering porosity and increasing strength. Shi and Stegmann [26] compared the acid resistance of several binders; alkali-activated slags (AASs), OPC binders, fly ash/lime binders (FAL) and high alumina cement $(\mathrm{AC})$, when immersed in nitric $(\mathrm{pH}=3)$ and acetic $(\mathrm{pH}=3$ e 5$)$ acid solutions. They reported that OPC binders presented higher mass losses than AAS and FAL binders while AC pastes were completely dissolved. According to these authors, OPC pastes are more porous than AAS but less porous than FAL pastes, so chemical attack is more influenced by the nature of hydration products than from porosity. They also reported that low $\mathrm{pH}$ acids are responsible for the highest chemical attack. Bakharev et al. [27] also compared OPC and alkali-activated slag concrete resistance to sulphat attack, reporting that the former showed a lower strength reduction, that could be explained due to the binder structure chemical differences. Bakharev et al. [28] studied OPC and slag concretes activated with $\mathrm{NaOH}$ and waterglass, immersed in an acetic acid solution $(\mathrm{pH}=4)$ during one year. They reported a 33\% strength loss for the former and $47 \%$ for OPC concretes. They claim that the strength loss is influenced by Ca content, 64\% for OPC concretes and just 39\% for alkali-activated slag concretes. Besides slag compounds have lower $\mathrm{Ca} / \mathrm{Si}$ molar ratio and are more stable in acid medium. As for OPC concrete calcium compounds, they possess high $\mathrm{Ca} / \mathrm{Si}$ molar ratios and react with acetic acid forming acetic calcium compounds which is very soluble. They concluded that concretes with less free calcium have a higher performance in acid medium. The work of Song et al. [29] also confirm that alkali-activated fly ash concretes possess high chemical resistance, when immersed in a $10 \%$ concentration sulphuric acid solution during 8 weeks, they showed mass and strength losses respectively of 3\% and 35\%. Gourley and Johnson [30] mentioned that a Portland cement concrete with a service life of 50 years lose $25 \%$ of its mass after 80 immersions cycles in a sulphuric acid solution $(\mathrm{pH}=1)$ while an alkaliactivated concrete required 1400 immersions cycles to lose the same mass, thus meaning a service life of 900 years. PachecoTorgal et al. [31] mentioned an average mass loss of just $2.6 \%$ after 
being submitted to the attack of (sulphuric, hydrochloric and nitric) acids during 28 days, while the mass loss for Portland cement concretes is more than twice that value. Those authors mention that weight loss results for mine waste binders are not very dependent from the type of acid, however, other authors [32-34] report different results for geopolymers based on fly ash and blast furnace slag.

\section{Alkali-silica reaction (ASR)}

The chance of ASR may take place in alkali-activated binders is an unknown subject. For OPC binders, however, the knowledge of ASR has been intensively studied; therefore some explanations could be also applied to understand the possibility of ASR when alkali-activated binders are used. ASR was reported by the first time by Stanton [35] and needs the simultaneous action of three elements in order to occur: (a) enough amorphous silica, (b) alkaline ions and (c) water [36]. The ASR begins when the reactive silica from the aggregates is attacked by the alkaline ions from cement forming an alkali-silica gel, which attracts water and starts to expand. The gel expansion leads to internal cracking, what have been confirmed by others [37] reporting $4 \mathrm{MPa}$ pressures. Those internal tensions are higher than OPC concrete tensile strength, thus leading to cracking. However some authors believe that ASR is not just a reaction between alkaline ions and amorphous silica but also requires the presence of $\mathrm{Ca}^{2+}$ ions [38]. Davidovits [39] compared alkali-activated binders and OPC binders when submitted to the ASTM C227 mortar-bar test, reporting a shrinkage behaviour in the first case and a serious expansion for the OPC binder. Other

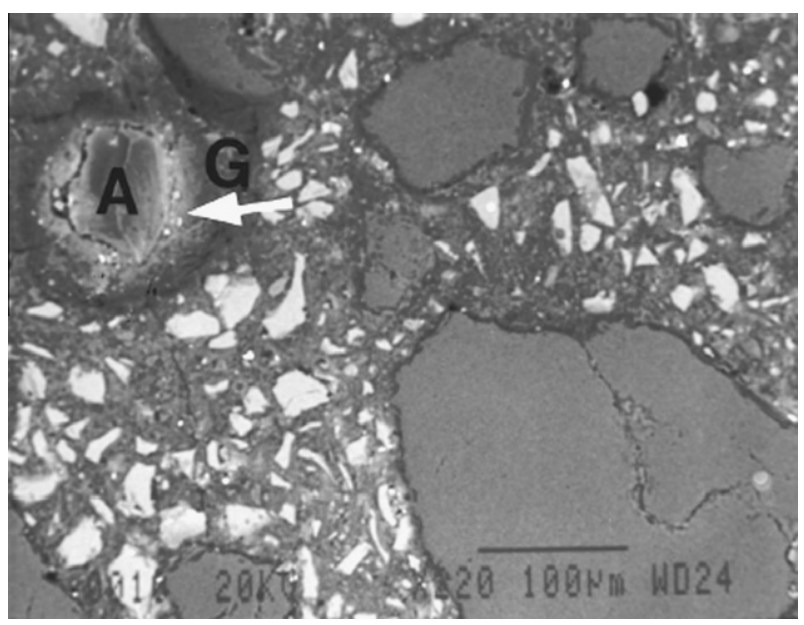

Fig. 1. Alkali-activated concrete after 10 months curing. (A) Reactive aggregate. (G) Alkali-silica gel [42]. authors [40] reported some expansion behaviour for alkali-activated binders although smaller than for OPC binders. However, Puertas [41] believe ASR could occur for alkali-activated slag binders containing reactive opala aggregates. Bakharev et al. [42] compared the expansion of OPC and alkali-activated binders reporting that the first ones had higher expansion. This is clear from the microstructure analysis (Fig. 1). García-Lodeiro et al. [43] showed that alkali-activated fly ash is less susceptible to generate expansion by alkali-silica reaction than OPC. They also showed that the calcium plays an essential role in the expansive nature of the gels. Recent investigations [44] show that siliceous aggregates are more prone to ASR than calcareous aggregates in alkali-activated mixtures. Therefore the study of ASR, in alkali-activated binders is not a closed subject, at least for the mixtures containing calcium.

\section{Corrosion of steel reinforcement}

The corrosion of steel reinforcement is one the causes that influences the structural capability of concrete elements. As concrete attack depends on its high volume and therefore is not of great concern, an attack to the steel reinforced bars is a serious threat eased by the fact that steel bars are very near of concrete surface and are very corrosion sensitive. In OPC binders, steel bars are protected by a passivity layer, due to the high alkalinity of calcium hydroxide. The steel bars corrosion may happen if $\mathrm{pH}$ decreases thus destroying the passivity layer, due to carbonation phenomenon or chloride ingress. The steel corrosion occurs due to an electrochemical action, when metals of different nature are in electrical contact in the presence of water and oxygen. The process consists in the anodic dissolution of iron when the positively charged iron ions pass into the solution and the excess of negatively charged electrons goes to steel through the cathode, where they are absorbed by the electrolyte constituents to form hydroxyl ions. These in turn combine with the iron ions to form ferric hydroxide, which then converts to rust. The volume increase associated with the formation of the corrosion products will lead to cracking and spalling of the concrete cover. For alkali-activated binders the literature is small about its capability to prevent reinforced steel corrosion. Some studies about chloride diffusion clearly show that alkali-activated binders are able to prevent the ingress of harmful elements that could start steel corrosion. Roy et al. [45] compared chloride diffusion for OPC and alkali-activated binders reporting that the former presented almost half of the diffusion values of the OPC binders. Saraswathy et al. [46] studied alkali-activated fly ash mixtures reporting a steel corrosion resistance similar to the one OPC binders. Miranda et al. [47] even demonstrated that alkali-activated fly ash binders have superior $\mathrm{pH}$ conditions than OPC binders. They reported that $\mathrm{pH}$ decreased with hydration reaction development, however an alkaline condi-

\section{Binder content}

$300 \mathrm{~kg} / \mathrm{m}^{3}$

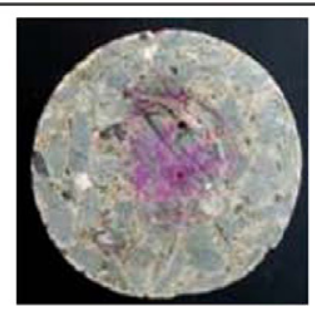

$400 \mathrm{~kg} / \mathrm{m}^{3}$

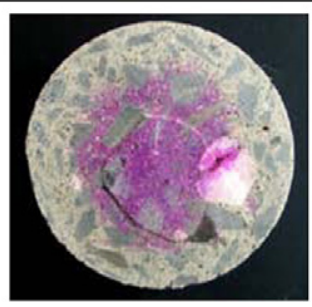

$500 \mathrm{~kg} / \mathrm{m}^{3}$

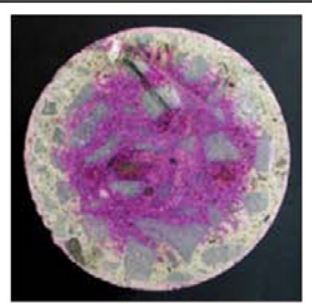

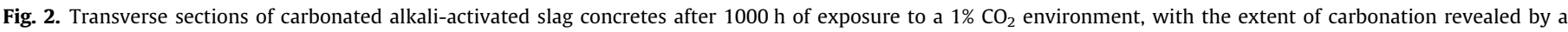
phenolphthalein indicator. Samples are $76.2 \mathrm{~mm}$ in diameter [50]. 
tion remained even after 5 years, since carbonation phenomenon ad not take place. Aperador et al. [48] mention that alkali-activated slag concrete is associated to poor carbonation resistance a major cause for corrosion of steel reinforcement. Bernal et al. [49] shows that the activation of granulated blast furnace slag (GBFS)-metakaolin (MK) blends have low carbonation resistance. The same authors [50] found that alkali-activated slag concretes present some susceptibility to carbonation which depends on the binder content (Fig. 2). Lloyd et al. [51] show that geopolymer cement is prone to alkali leaching leading to a reduction in the $\mathrm{pH}$ which is essential to prevent steel corrosion. They also mention that the presence of calcium is crucial for having "durable steel-reinforced concrete" which is a setback for $\mathrm{Si}-\mathrm{Al}$ geopolymers. Further research about reinforced steel corrosion is therefore needed, concerning alkalinity stability with curing time, as well as about chloride diffusion and carbonation resistance.

\section{Resistance to high temperatures and to fire}

Concretes based on Portland cement show a weak performance when subjected to a thermal treatment and when the temperature rises above $300{ }^{\circ} \mathrm{C}$ they begin to disintegrate. As to the alkali-activated binders they show a high stability when submitted to high temperatures even around $1000{ }^{\circ} \mathrm{C}$ [52]. Other authors [53] studied the activation of metakaolin and shale wastes reporting a high mechanical performance after a thermal phase. The specimens show some slight strength loss between $600^{\circ} \mathrm{C}$ and $1000^{\circ} \mathrm{C}$, however in some cases they show a strength increase at $1200^{\circ} \mathrm{C}$. Kong et al. [54] studied alkali-activated metakaolin binders observing that the residual strength after a thermal phase up to $800^{\circ} \mathrm{C}$ is influenced by the $\mathrm{Si} / \mathrm{Al}$ ratio. The higher residual strength was obtained by the mixtures with a Si/Al ratio between 1.5 and 1.7. Krivenko and Guziy [55] found that alkali-activated binders show a high performance in the resistance to fire, thus suggesting that this material is suitable for use in works with a high fire risk like tunnels and tall buildings. Perná et al. [56] confirmed that alkali-activated binders can be used as a $120 \mathrm{~min}$ anti-fire material in accordance with related standards of the Czech Republic. The anti-fire material must show a temperature lower than $120^{\circ} \mathrm{C}$ in the opposite side of the fire action. Temuujin et al. [57] used alkali-activated binders as steel coatings stating that they maintained high structural integrity even after being submitted to a heat treatment by a gas torch. Zhao and Sanjayan [58] compared the performance of OPC concrete and alkali activated concrete under the standard curve fire test mentioning that only the former exhibit spalling behaviour. The internal pore structure of the latter allows a quick escape of the water vapour resulting in lower internal pore pressure.

\section{Resistance to freeze-thaw}

According to Yunsheng and Wei [59] alkali-activated fly ash can withstand 2.2 times more freeze-thaw cycles as compared to concrete made from OPC with the same compressive strength. Dolezal et al. [60] reported the loss of only $30 \%$ of the resistance in alkaliactivated fly ash binders after being subjected to 150 freeze-thaw cycles. Other authors [61] analyzed the resistance of alkali-activated slag-waste shales based binders reporting a high compressive strength even after freeze-thaw 100 cycles. Slavik et al. [62] obtained high freeze-thaw resistance in alkali-activated binders based on fluidized bed combustion bottom ash. The investigations of Brooks et al. [63] confirm the high resistance to freeze-thaw of the alkali-activated binders. More recently Fu et al. [64] studied alkali-activated slag concrete reporting an excellent freeze-thaw resistance.

\section{Efflorescences}

The subject of efflorescences in alkali-activated binders is relatively new, since very few authors have addressed this problem. According to Skvara et al. $[65,66]$ the bond between the sodium ions $\left(\mathrm{Na}^{+}\right)$and the aluminosilicate structure is weak and that explains the leaching behaviour. According to those authors in the crystalline zeolites the leaching of sodium is negligible contrary to what happens in the aluminosilicate polymers. It is the presence of water that weakens the bond of sodium in the aluminosilicate polymers, a behaviour that is confirmed by the alkali-activated binder structure model. Pacheco-Torgal and Jalali [67] also found that sodium efflorecences are higher in alkali-activated binders based on aluminosilicate prime materials calcined at a temperature range below the dehydroxylation temperature with the addition of sodium carbonate as a source of sodium cations (Fig. 3). Temuujin et al. [68] refer that although ambient cured fly ash alkali-activated binders exhibited efflorescences that phenomena does not occur when the same alkali-activated binders are cured at elevated temperature which means the leachate sodium could be a sign of insufficient geopolymerisation. Recently Van Deventer et al. [69] recognized that current two part geopolymers suffer from severe efflorescence which is originated by the fact that "alkaline and/or soluble silicates that are added during processing cannot be totally consumed during geopolymerisation". Only recently Kani et al. [70] showed that efflorescences can be reduced either by the addition of alumina-rich admixtures or by hydrothermal curing at temperatures of $65^{\circ} \mathrm{C}$ or higher. These authors found that the use of $8 \%$ of calcium aluminate cement greatly reduces the mobility of alkalis leading to minimum efflorescences (this cement has $28 \%$ of $\mathrm{CaO}$ ) (Fig. 4). These results are very important because
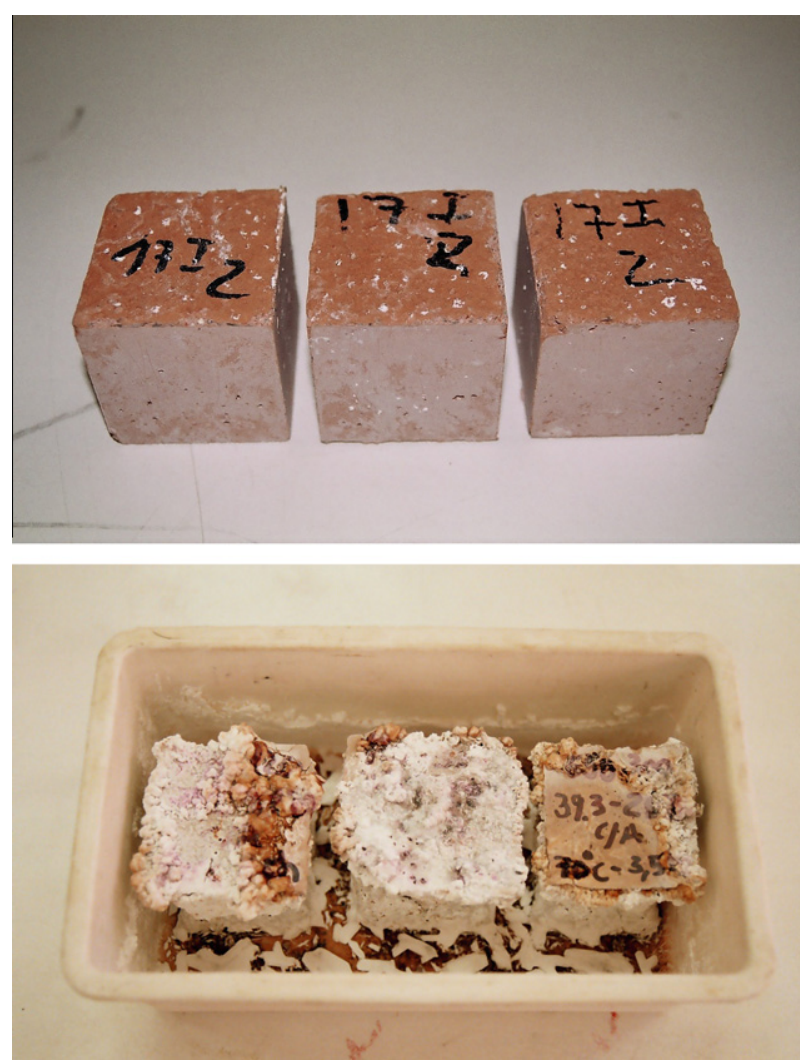

Fig. 3. Alkali-activated mine mortars specimens after water immersion: Above mortars based on plain mine waste mud calcined at $950{ }^{\circ} \mathrm{C}$ for $2 \mathrm{~h}$; Below mortars based on mine waste mud calcined at different temperatures with sodium carbonate [67]. 


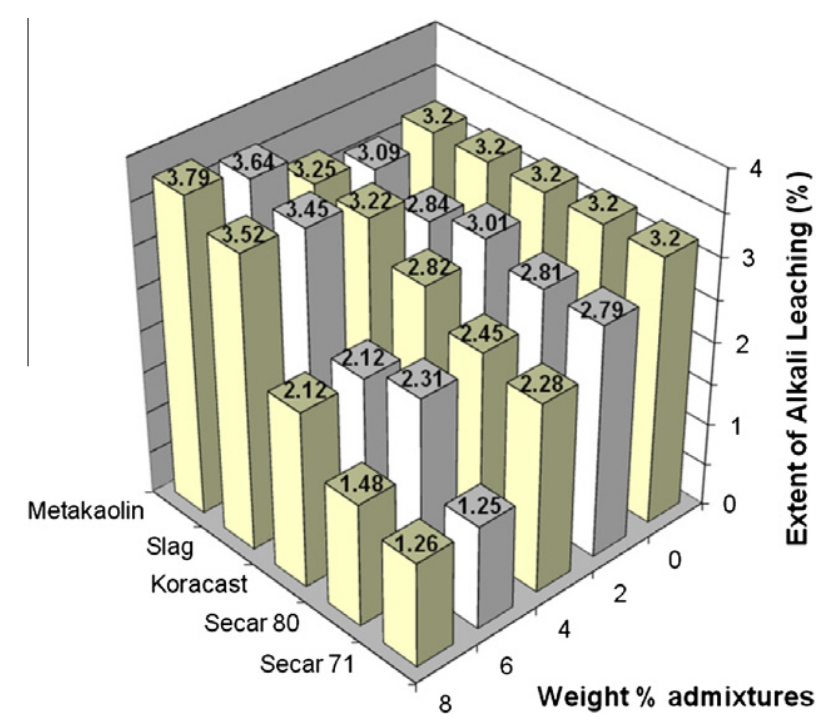

Fig. 4. Effect of admixtures on alkali leaching (as a proxy for efflorescence extent) [70].

they constitute a step back in the development of alkali-activated binders. For one the use of hydrothermal curing has serious limitations for on-site concrete placement operations. On the other hand the use of calcium based mixtures reduces the acid resistance and raises the chances for the occurrence of ASR. Besides the use of such calcium content reduces the global warming emissions advantage over Portland cement.

\section{Conclusions}

The literature review about the durability of alkali-activated binders shows that:

(a) New investigations are needed on the use of sodic wastes to replace sodium silicate in order to reduce the cost of these materials.

(b) The new binders present higher chemical resistance, however it seems that depends more on the low content of soluble calcium compounds than it is from their low permeability.

(c) Although these binders contain a high level of alkali elements, they do not appear to be associated with the occurrence of ASR, which may be due to the fact that the majority of alkali elements are associated with other reaction products. However that explanation forgets the crucial role played by calcium in the ASR development meaning that although its rather natural the absence of ASR in free calcium alkali-activated binders, that problem must be taken under consideration when calcium based binders were used.

(d) As to the capability to keep an alkaline environment trough time, which is crucial to maintain reinforced steel safe from corrosion, the current studies are not enough to prove it, as a matter of fact their resistance to carbonation is lower than OPC binders and recent investigation show that it is difficult to synthesize a low-Ca geopolymer capable of preserving the steel reinforcement passivation film.

(e) The use of calcium in alkali-activated binders is indispensable to keep a high $\mathrm{pH}$ but at the same time could be the responsible for triggering ASR.

(f) Contrary to standard OPC binders alkali-activated binders show a high stability when submitted to high temperatures which dependent on the $\mathrm{Si} / \mathrm{Al}$ ratio. The investigations on the fire behaviour of alkali-activated binders show that these materials are specially recommended for works with a high fire risk like tunnels and tall buildings.

(g) Alkali-activated binders show a high resistance to freezethaw cycles.

(h) Alkali-activated binders are prone to the formation of efflorescence's however this disadvantage can be greatly reduce when using hydrothermal curing treatments or calcium aluminate admixtures. Nevertheless, hydrothermal curing has limited applications for on situ concrete placement operations and the use of a calcium based admixture raises issues about its acid resistance. Furthermore, alkali-activated binders containing calcium based admixture have a higher global warming impact than alkali-activated $\mathrm{Si}-\mathrm{Al}$ mixtures.

\section{References}

[1] Juenger M, Winnefeld F, Provis J, Ideker J. Advances in alternative cementitious binders. Cem Concr Res 2011;41:1232-43.

[2] Gartner E. Industrially interesting approaches to low- $\mathrm{CO}_{2}$ cements. Cem Concr Res 2004;34:1489-98.

[3] Damtoft J, Lukasik J, Herfort D, Sorrentino D, Gartner E. Sustainable development and climate change initiatives. Cem Concr Res 2008;38:115-27.

[4] Ali M, Saidur R, Hossain M. A review on emission analysis in cement industries. Renew Sust Energy Rev 2011;15:2252-61.

[5] Taylor M, Gielen D. Energy efficiency and $\mathrm{CO}_{2}$ emissions from the global cement industry. Int Energy Agency 2006.

[6] Pacheco-Torgal F, Gomes J, Jalali Said. Alkali - activated binders: a review Part 1: Historical background, terminology, reaction mechanisms and hydration products. Constr Build Mater 2008;22:1305-14.

[7] Pacheco-Torgal F, Gomes J, Jalali Said. Alkali - activated binders: a review Part 2: About materials and binders manufacture. Constr Build Mater 2008;22:1315-22.

[8] Li C, Sun H, Li L. A review: the comparison between alkali-activated slag $(\mathrm{Si}+\mathrm{Ca})$ and metakaolin $(\mathrm{Si}+\mathrm{Al})$ cements. Cem Concr Res 2010;40:1341-9.

[9] Davidovits J, Comrie DC, Paterson JH, Ritcey DJ. Geopolymeric concretes for environmental protection. ACI Concr Int 1990;12:30-40.

[10] Duxson P, Provis J, Luckey G, Van Deventer J. The role of inorganic polymer technology in the development of "Green Concrete". Cem Concr Res 2007;37:1590-7.

[11] Duxson P, Van Deventer J. In: Provis J, Van Deventer J, editor. Geopolymers, structure, processing, properties and applications. Cambridge, UK: Woodhead Publishing Limited Abington Hall; 2009 [ISBN -13: 978184569449 4].

[12] Weil M, Dombrowski K, Buchawald A. Life-cycle analysis of geopolymers. In: Provis J, Van Deventer J, editor. Geopolymers, structure, processing, properties and applications. Woodhead Publishing Limited Abington Hall, Cambridge, UK; 2009. p. 194-210 [ISBN -13: 978184569449 4].

[13] McLellan B, Williams R, Lay J, Van Riessen A, Corder G. Costs and carbon emissions for geopolymer pastes in comparison to ordinary Portland cement. J Cleaner Prod 2011;19:1080-90.

[14] Habert G, de Lacaillerie J, Roussel N. An environmental evaluation of geopolymer based concrete production: reviewing current research trends. J Cleaner Prod 2011;11:1229-38.

[15] Laldji S, Tagnit-Hamou A. Glass frit for concrete structures: a new alternative cementitious material. Can J Civil Eng 2007;34:793-802.

[16] ERMCO (2011) Statistics of the year 2010. Boulevard du Souverain 68, B-1170 Brussels, Belgium; 2011.

[17] Pacheco-Torgal F, Gomes JP, Jalali Said. Tungsten mine waste geopolymeric binders. Preliminary hydration products. Constr Build Mater 2009;23:200-9.

[18] Pacheco-Torgal F, Gomes JP, Jalali Said. Investigations on mix design of tungsten mine waste geopolymeric binders. Constr Build Mater 2008;22:1939-49.

[19] Pacheco-Torgal F, Gomes JP, Jalali Said. Properties of tungsten mine waste geopolymeric binder. Constr Build Mater 2008;22:1201-11.

[20] Pacheco-Torgal F, Gomes J, Jalali S. Adhesion characterization of tungsten mine waste geopolymeric binder. Influence of OPC concrete substrate surface treatment. Constr Build Mater 2008;22:154-61.

[21] Provis JL, Muntingh Y, Lloyd RR, Xu H, Keyte LM, Lorenzen L, et al. Will geopolymers stand the test of time? Ceram Eng Sci Proc 2008;28:235-48.

[22] Van Deventer JSJ, Provis J, Duxson P. Technical and commercial progress in the adoption of geopolymer cement. Minerals Engineering (in press).

[23] Glukhovsky VD. Slag-alkali concretes produced from fine-grained aggregate. Kiev: Vishcha Shkolay; 1981.

[24] Jiang W, Silsbee MR, Breval E, Roy MD. Alkali-activated cementitious materials in chemically aggressive environments. In: Young JF, editor. Mechanisms of chemically degradation of cement-based systems. E\&FN SPON (1997) London; 1997. p. 289-96.

[25] Palomo A, Blanco-Varela MT, Granizo ML, Puertas F, Vasquez T, Grutzeck MW Chemical stability of cementitious materials based on metakaolin. Cem Concr Res 1999;29:997-1004. 
[26] Shi Caijun, Stegmann JA. Acid corrosion resistance of different cementing materials. Cem Concr Res 2000;30:803-8.

[27] Bakharev T, Sanjayan JG, Cheng YB. Sulfate attack on alkali-activated slag concrete. Cem Concr Res 2002;31:211-6.

[28] Bakharev T, Sanjayan JG, Cheng YB. Resistance of alkali-activated slag concrete to acid attack. Cem Concr Res 2003;33:1607-11.

[29] Song X, Marosszeky M, Brungs M, Munn R. Durability of fly ash based geopolymer concrete against sulphuric acid attack. In: 10th International conference on the durability of building materials and components. Lyon France; 2005.

[30] Gourley JT, Johnson GB. Developments in geopolymer precast concrete. In: Proc of Geopolymer 2005 World Congress, 139-143, geopolymer green chemestry and sustainable development solutions, S. Quentin, France; 2005.

[31] Pacheco-Torgal F, Gomes J, Jalali S. Durability and environmental performance of alkali-activated tungsten mine waste mud mortars. J Mater Civil Eng 2010;22:897-904.

[32] Allahverdi A, Škvára F. Nitric acid attack on hardened paste of geopolymeric cements - Part 1. Ceram-Silikaty 2001;45:81-8.

[33] Allahverdi A, Škvára F. Nitric acid attack on hardened paste of geopolymeric cements - Part 2. Ceram-Silikaty 2001;45:143-9.

[34] Allahverdi A, Škvára F. Sulfuric acid attack on hardened paste of geopolymer cements. Part 1 . Mechanism of corrosion at relatively high concentrations. Ceram-Silikaty 2005;49:225-9.

[35] Stanton TE. Influence of cement and aggregate on concrete expansion. Eng News Record 1940;1:50-61.

[36] Sims I, Brown B. Concrete aggregates. In: Hewlett PC, editor. Leás chemestry of cement and concrete, 4th ed. London; 1998. p. 903-89.

[37] Wood JG, Johnson RA. The appraisal and maintenance of structures with akalisilica reaction. The Struct Eng 1993;71(2).

[38] Davies D, Oberholster RE. Alkali-silica reaction products and their development. Cem Concr Res 1988;18:621-35.

[39] Davidovits J. Geopolymers: inorganic polymeric new materials. J Therm Anal 1991;37:1633-56.

[40] Fernandez-Jimenez A, Puertas F. The alkali-silica reaction in alkali-activated slag mortars with reactive aggregate. Cem Concr Res 2002;32:1019-24.

[41] Puertas F. Cementos de escórias activadas alcalinamente. Situacion actual y perpectivas de futuro. Mater Constr 1995;45:53-64.

[42] Bakharev T, Sanjayan JG, Cheng YB. Resistance of alkali-activated slag to alkali-aggregate reaction. Cem Concr Res 2001;31:331-4.

[43] García-Lodeiro I, Palomo A, Fernández-Jiménez A. Alkali-aggregate reaction in activated fly ash systems. Cem Concr Res 2007;37:175-83.

[44] Puertas F, Palacios M, Gil-Maroto A, Vázquez T. Alkali-aggregate behaviour of alkali-activated slag mortars: effect of aggregate type. Cem Concr Compos 2009;31:277-84.

[45] Roy DM, Jiang W, Silsbee MR. Chloride diffusion in ordinary blended and alkali-activated cement pastes. Cem Concr Res 2000;30:1879-84.

[46] Saraswathy V, Muralidharan S, Thangavel K, Srinivasan S. Influence of activated fly ash on corrosion resistance and strength of concrete. Cem Concr Res 2003;25:673-80.

[47] Miranda JM, Fernandez-Jimenez A, Gonzalez A, Palomo A. Corrosion resistance in activated fly ash mortars. Cem Concr Res 2005;35:1210-7.

[48] Aperador W, de Gutiérrez R, Bastidas D. Steel corrosion behaviour in carbonated alkali-activated slag concrete. Corros Sci 2009;51:2027-33.

[49] Bernal S, de Gutiérrez R, Pedraza A, Provis J, Rose V. Effect of silicate modulus and metakaolin incorporation on the carbonation of alkali silicate-activated slags. Cem Concr Res 2010;40:898-907.

[50] Bernal S, de Gutiérrez R, Pedraza A, Provis J, Rodriguez E, Delvasto S. Effect of binder content on the performance of alkali-activated slag concretes. Cem Concr Res 2011;41:1-8.
[51] Lloyd R, Provis J, Van Deventer SJS. Pore solution composition and alkali diffusion in inorganic polymer cement. Cem Concr Res 2010;40: 1386-92.

[52] Pawlasova S, Skavara F. High-temperature properties of geopolymer materials. In: Alkali activated materials - research, production and utilization 3rd conference, Prague, Czech Republic; 2007. p. 523-4.

[53] Bortnovsky O, Dvorakova K, Roubicek P, Bousek J, Prudkova Z, Baxa P. Development, properties and production of geopolymers based on secondary raw materials. In: Alkali activated materials - research, production and utilization 3rd conference, Prague, Czech Republic; 2007. p. 83-96.

[54] Kong D, Sanjayan J, Sagoe-Cretensil K. Factors affecting the performance of metakaolin geopolymers exposed to elevated temperatures. J Mater Sci 2008;43:824-31.

[55] Krivenko P, Guziy S. Fire resistant alkaline Portland cements. In: Alkali activated materials - research, production and utilization 3rd conference, Prague, Czech Republic; 2007. p. 333-47.

[56] Perná I, Hanzlicek T, Straka P, Steinerova M. Utilization of fluidized bed ashes in thermal resistance applications. In: Alkali activated materials - research, production and utilization 3rd conference, Prague, Czech Republic; 2007. p. 527-37.

[57] Temuujin J, Rickard W, Lee M, Van Riessen A. Preparation and thermal properties of fire resistant metakaolin-based geopolymer-type coatings. J NonCryst Solids 2011;357:1399-404.

[58] Zhao R, Sanjayan JG. Geopolymer and Portland cement concretes in simulated fire. Mag Concr Res 2011;63(3):163-73.

[59] Yunsheng Z, Wei S. Fly ash based geopolymer concrete. Indian Concr J 2006;80:20-4.

[60] Dolezal J, Skvara F, Svoboda P, Sulc R, Kopecky L, Pavlasova S, Myskova L, Lucuk M, Dvoracek K. Concrete based on fly ash geopolymers. In: Alkali activated materials - research, production and utilization 3rd conference, Prague, Czech Republic; 2007. p. 185-97.

[61] Bortnovsky O, Dvorakova K, Roubicek P, Pousek J, Prudkova Z, Baxa P. Development, properties and production of geopolymers based on secondary raw materials. In: Alkali activated materials - research, production and utilization 3rd conference, Prague, Czech Republic; 2007. p. 83-96.

[62] Slavik R, Bednarik V, Vondruska M, Nemec A. Preparation of geopolymer from fluidized bed combustion bottom ash. J Mater Process Technol 2008;200:265-70.

[63] Brooks R, Bahadory M, Tovia F, Rostami H. Properties of alkali-activated fly ash: high performance to lightweight. Int J Sust Eng 2010;3:211-8.

[64] Fu Y, Cai L, Wu Y. Freeze-thaw cycle test and damage mechanics models of alkali-activated slag concrete. Constr Build Mater 2011;25: 3144-8.

[65] Skvara F, Kopecky L, Smilauer V, Alberovska L, Bittner Z. Material and structural characterization of alkali activated low-calcium brown coal fly ash. J Hazard Mater 2008;168:711-20.

[66] Skvara F, Kopecky L, Smilauer V, Alberovska L, Vinsova L. Aluminosilicate polymers - influence of elevated temperatures, efflorescence. Ceram-Silikaty 2009;53:276-82.

[67] Pacheco-Torgal F, Jalali S. Influence of sodium carbonate addition on the thermal reactivity of tungsten mine waste mud based binders. Constr Build Mater 2010;24:56-60.

[68] Temuujin J, Van Riessen A, Williams R. Influence of calcium compounds on the mechanical properties of fly ash geopolymer pastes. J Hazard Mater 2009;167:82-8.

[69] Van Deventer JSJ, Feng D, Duxson P. Dry mix cement composition, methods and systems involving same. US Patent 7691,198 B2; 2010.

[70] Kani E, Allahverdi A, Provis J. Efflorescence control in geopolymer binders based on natural pozzolan. Cem Concr Compos 2011;34:25-33. 